OPEN ACCESS

Edited by:

Urs Feller:

University of Bern, Switzerland

Reviewed by:

Qinfeng Guo,

United States Forest Service (USDA),

United States

Karl Kunert,

University of Pretoria, South Africa

${ }^{*}$ Correspondence:

Adriana E. Rovere

adrirovere@gmail.com

Specialty section:

This article was submitted to Agroecology and Land Use Systems, a section of the journa

Frontiers in Ecology and Evolution

Received: 06 September 2017 Accepted: 11 December 2017 Published: 22 December 2017

Citation:

Betancurt $R$, Rovere AE and Ladio AH

(2017) Incipient Domestication

Processes in Multicultural Contexts: A Case Study of Urban Parks in San Carlos de Bariloche (Argentina).

Front. Ecol. Evol. 5:166 doi: 10.3389/fevo.2017.00166

\section{Incipient Domestication Processes in Multicultural Contexts: A Case Study of Urban Parks in San Carlos de Bariloche (Argentina)}

\author{
Romina Betancurt ${ }^{1}$, Adriana E. Rovere ${ }^{2 *}$ and Ana H. Ladio ${ }^{3}$ \\ ${ }^{1}$ INIBIOMA, CONICET, Universidad Nacional del Comahue, Bariloche, Argentina, ${ }^{2}$ CONICET-Universidad Nacional del \\ Comahue, Bariloche, Argentina, ${ }^{3}$ Ethnobiology Group, INIBIOMA CONICET, Universidad Nacional del Comahue, Bariloche, \\ Argentina
}

Up to now, the processes of domestication of urban landscapes have been little studied. The public green spaces in the city of Bariloche, an enclave with growing urbanization which lies within the Andino Norpatagonica Biosphere Reserve, offer an opportunity to evaluate cultural molding of the environment. We analyzed different management methods of woody species, both in situ and ex situ, in parks located in sectors with different environmental, socioeconomic, size, age and administration characteristics. Our hypotheses were: (1) Species richness will be higher for exotic plants, in accordance with global patterns of ornamental species selection. (2) Species richness and type of management practice will vary according to the kind of environment, the socioeconomic profile of the neighborhood, the age and size of the park, and type of administration (bottom-up or top-down). (3) Bottom-up park administration will lead to a different landscape than top-down administration. Thirty randomly selected parks of both local council and neighborhood administration and varying environmental and socioeconomic conditions were examined and the composition of their woody species identified. In addition, semi-structured and free interviews were carried out with those responsible for park management, both in situ (tolerance, enhancement, protection) and ex situ (sowing, use of cuttings or transplanting). In accordance with our hypothesis, the processes of domestication of the urban landscape show a tendency toward an anthropized diversity of 130 species, mainly exotic in origin (72\%), and principally from the Holarctic region (67\%). However, multinomial logistic analysis revealed that in parks under neighborhood administration tolerance of native species is higher (13 times) than in parks administrated by the local council. Species richness increases along an environmental and socioeconomic gradient, and with the age of parks, but does not vary with size. We conclude that urban parks are constructed cultural niches which, as in an agroforestry system, are scenarios which reveal processes of incipient domestication that reflect different cosmovisions and drivers typical of multicultural contexts.

Keywords: biosphere reserve, cultural niche construction, domestication, ornamental species, urban spaces, woody plant diversity 


\section{INTRODUCTION}

Human beings have been the principal drivers of change in the earth's ecological systems since the Holocene, 10,000 years ago (Smith and Zeder, 2013; Zeder, 2015). Molding of landscapes and domestication of plants and animals are some of the most important humanization processes (Kareiva et al., 2007). Due to the fact that the world population is concentrated in cities, these environments are currently the focus of particular interest (Pataki, 2015).

Cities are often described as new ecosystems or "novel ecosystems," since there were no analogous natural ecosystems previous to human population (Hobbs et al., 2006), and they are even called "novel biomes" (Pincetl, 2016). These urban ecosystems contain microenvironments and biological ensembles (such as urban parks), which in contrast to natural remnant ecosystems are constructed and designed by their inhabitants (Grimm et al., 2000). Urban vegetation is unique in that it consists of new assemblages of native and exotic tree species influenced by the biophysical conditions of the site, such as climatic factors, and also human drivers such as management or planting preferences (Aronson et al., 2015).

Urban parks can be seen as landscapes that synthesize the multiple interests (material, symbolic, emotional, etc.) of urban societies with their plant surroundings. They are essential spaces in the lives of city dwellers for various reasons, whether ecological, sociocultural or scenic (Finol, 2005; Tella and Potocko, 2009). Parks which have vegetation as a basic element of their composition can be defined as "green spaces," that is, public spaces which, due to the presence of plants, contribute to the wellbeing of their users and provide optimal conditions for sports or games, relaxation and rest (Saillard, 1962; Rodríguez-Laredo, 2008; Linhares de Souza et al., 2012). These spaces also have a role to play in the ecosystem, since they can act as a reservoir of biodiversity and wildlife (Ladio and Damascos, 2000; Rudd et al., 2002; McKinney, 2006; Nagendra and Gopal, 2011), as biological corridors facilitating connectivity with nearby conservation units (Rudd et al., 2002; Rovere and Molares, 2012), and as water flow regulators (Tella and Potocko, 2009; Argañaraz and Lorenz, 2010). Their role is currently so significant that the presence of a number of parks in a city is included as one of the principal indicators of urban habitability (Van Herzele and Wiedemann, 2003).

Even though parks have been managed in different ways to favor the wellbeing of those who use them for diverse reasons (Rozzi et al., 2003; Luck et al., 2009), they have been little studied using an ethnoecological approach. From this perspective we consider as management practices those actions which lead to the maintenance of, or even increase in, the biodiversity or abundance of plant species in an area, in such a way that their sustainability over time is favored (Berkes and DavidsonHunt, 2006; Moreno-Calles et al., 2010). The domestication of species and landscapes is a particularly important consequence of the management of species of interest, and also those of no interest, given that they are often eliminated. In the case of species of interest, a process is carried out through artificial selection whereby humans choose individuals with certain heritable characteristics, which modifies the genetic, morphological and functional composition of the populations (Casas et al., 2014, 2016). Specifically, this incipient domestication process refers to a state that depends on the level of management intensity of plant populations, where the average phenotype of the selected character is maintained within the range of variation found under natural conditions (Clement, 1999).

These interventions, transformations or decisions regarding the elements and functional processes of natural or artificial systems have explicit socio-cultural objectives (Casas et al., 2014). According to current thinking, these practices are linked to the idea of niche construction (Zeder, 2015), a process through which organisms, by means of their activities and options, modify their own niches in order to transform the pressure of natural selection. This concept is particularly pertinent in the case of humanization processes, where considerable environmental modification is occasioned through cultural practices (Laland and O'Brien, 2011; Smith, 2011).

Casas et al. (1996) have identified different landscape management practices; in situ, which are carried out within the distribution area of the plant species, and ex situ, in sites where a species is not normally found. The first case includes situations where different components, whether native or exotic flora, are tolerated and allowed to grow, or are protected, particularly from frost and/or pests, or are weeded and pruned to favor flowering or fruiting, amongst other cultural care practices (González-Insuasti and Caballero, 2007; Eyssartier et al., 2011; Moreno-Calles et al., 2012; Parra et al., 2012). In ex situ management, on the other hand, plants may be specially cultivated by seed, cuttings and/or seedlings (Blancas et al., 2010; Duque-Brasil et al., 2011) obtained from wild areas (Eyssartier et al., 2011; Moreno-Calles et al., 2012; Parra et al., 2012), plant nurseries and/or nearby gardens.

Urban flora has been studied from different points of view, but principally from the perspective of urban ecology. It has been found, for example, that socio-economic and environmental drivers are important in determining patterns of urban plant richness (Luck et al., 2009; Avolio et al., 2015); for example, proprietors' incomes correlate positively with plant richnessa relationship which has been defined as the "luxury effect" (Hope et al., 2003). Urban flora can thus be considered as a mosaic of small, public or private plots or patches along social and environmental gradients, such that each plot has its own set of drivers, and is molded by the kind of management or administration it is subject to Avolio et al. (2015).

Analysis of changes or the impact of urbanization on local ecosystems has been related to socioeconomic (e.g., income, level of education) and/or environmental (e.g., precipitation, soil fertility) drivers (Luck et al., 2009; Avolio et al., 2015). Plurality of owners and custody types, for example of urban parks, can therefore contribute enormously to the diversity of management styles of the vegetation, thus influencing the structure, composition and distribution of plant communities throughout the urban landscape (Avolio et al., 2016). For example, decisions on management may be top down, like those imposed by planning guides, conservation obligations or owners' associations, or they can be bottom-up, such as those carried out 
by individuals hired to manage the space, local groups of friends or individual residents and garden owners (Kendal et al., 2012).

Preliminary studies show that the selection of plant species for green spaces in cities is not a random process, but depends rather on decisions taken principally by municipal governments (Informe Ambiental Annual, 2008; Tella and Potocko, 2009; Rovere et al., 2013). However, those using the spaces often participate as principal actors, individually or collectively, whether representing neighborhood initiatives, NGOs, societies or institutions, public or private, and they also play a significant role in the conformation, care and use of these spaces. This landscape, therefore, is created and recreated by urban dwellers under different forms of custody, following diverse motives that may be sociocultural, economic, conservationist and/or symbolic in nature, amongst others (Rovere et al., 2013).

It has been found that there are global selection patterns for ornamental plants, to guide societies, principally in temperate areas, with the result that their flowers are very similar to each other, and are dominated by the Rosaceae and Asteraceae families (Rovere et al., 2013). Added to this are cultural forces, such as the desire to imitate landscape criteria used in northern hemisphere countries, a phenomenon observed, for example, in the creation of different Patagonian cities in Chile and Argentina, generating a selection by inhabitants that is oriented toward exotic species (Rozzi et al., 2003; Rovere et al., 2013).

Characterization of the use of urban spaces, in this case urban parks, is complex and dynamic, and involves numerous factors that could determine detectable gradients (Juri and Chani, 2005). In this sense, urban green spaces could be scenarios where, through the action of their inhabitants, the horizontal and vertical diversification of species in the landscape is enriched, or simply where small patches of native plants from the surrounding area are conserved (Ospina-Ante, 2003). The function and ecological sustainability of urban landscapes is strongly influenced by the composition and structure of the local plant community (Threlfall et al., 2016). However, they may also be a source of propagules of invasive species which can cause serious environmental and economic damage (Ladio and Damascos, 2000; Rovere and Molares, 2012; Rovere et al., 2013). The detailed study of practices, selection and maintenance of species in urban parks is therefore of considerable importance in terms of conservation, as well as contributing to reflection on the role of humans in the construction of this kind of niche.

This particular study was carried out in the city of San Carlos de Bariloche, situated within the Andino Norpatagonica Biosphere Reserve (UNESCO, 2010). The urbanization of this enclave is relatively new and in the process of growth, although with certain commitment in terms of conservation due to its situation within a nature reserve, which gives us an opportunity to evaluate the cultural molding of this environment due to human action. Our objectives were: to analyze species composition and different management methods in situ and ex situ of woody species in parks of San Carlos de Bariloche. The parks are distributed in sectors with environmental, socioeconomic, size, age, and management (bottom-up vs. topdown) differences. The principal hypotheses were: (1) Species richness will be greater for exotic species, in accordance with global selection patterns for ornamental species (2) Species richness and type of management practice will vary according to the environmental category, socioeconomic profile of the neighborhood, age and size of the park and type of administration (3) Bottom-up administration of parks will lead to a different landscape than top-down administration in San Carlos de Bariloche.

\section{METHODS}

\section{Study Location and Data Collection}

This study was carried out in the city of San Carlos de Bariloche $\left(41^{\circ} 08^{\prime} \mathrm{S}\right.$ and $\left.71^{\circ} 18^{\prime} \mathrm{W}\right)$, in the northwest of Argentine Patagonia (Rio Negro province). The city is situated in an Andean Patagonian forest environment that lies within the limits of Nahuel Huapi National Park. The city extends $45 \mathrm{~km}$, (the widest extension in the country) and covers a total surface area of 22,376 ha. The west-east gradient is very marked, principally due to a decrease in precipitation caused by the orographic effect of the Andes. Climate in the region is temperate-cold and humid, with a Mediterranean-like precipitation regime, with rains and snow principally in winter. The city, founded in 1902, has a population of 133,500 inhabitants (INDEC, 2010). The community is pluricultural, with Mapuche inhabitants (the principal indigenous group of Patagonia), European immigrants and new immigrants from other urban areas of the country. Tourism is the main economic activity (Chebez, 2005). A large part of the city adjoins native forest or is situated within small isolated wooded areas with different levels of anthropic disturbance, while other neighborhoods lie within the foreststeppe ecotone (Dzendoletas et al., 2006).

There are many parks distributed throughout the urban territory, constructed by different organizations, of different sizes, age, and types of management and administration. This study was carried out in different stages: firstly, an inventory was made of the woody species present in 30 parks within the city area (Figure 1), and secondly, participant observation and interviews were carried out.

\section{Composition of the Vegetation}

Identification of the woody flora was carried out during January and February of 2015, and from October 2015 to January of 2016, which correspond to spring and summer in the southern hemisphere, in order to find the highest possible number of species bearing flowers or fruit, since this aids identification. The botanical determination followed Correa (1971, 1984, 1988) and Dimitri (1977, 1978). All scientific names were updated using databases of the Instituto Darwinion (Zuloaga et al., 2008) and the Missouri Botanical Garden (www.tropicos.org). Plant specimens were placed in the Ecotono-University of Comahue herbarium. For each park, the name, size, geographical location, height, species composition and richness were recorded. Using the Instituto Darwinion and Missouri Botanical Garden databases, the botanical family each species belonged to was registered, plus its biogeographical origin (native or exotic). We considered a species as native if its natural distribution was found within Argentina, whereas those which arrived in 


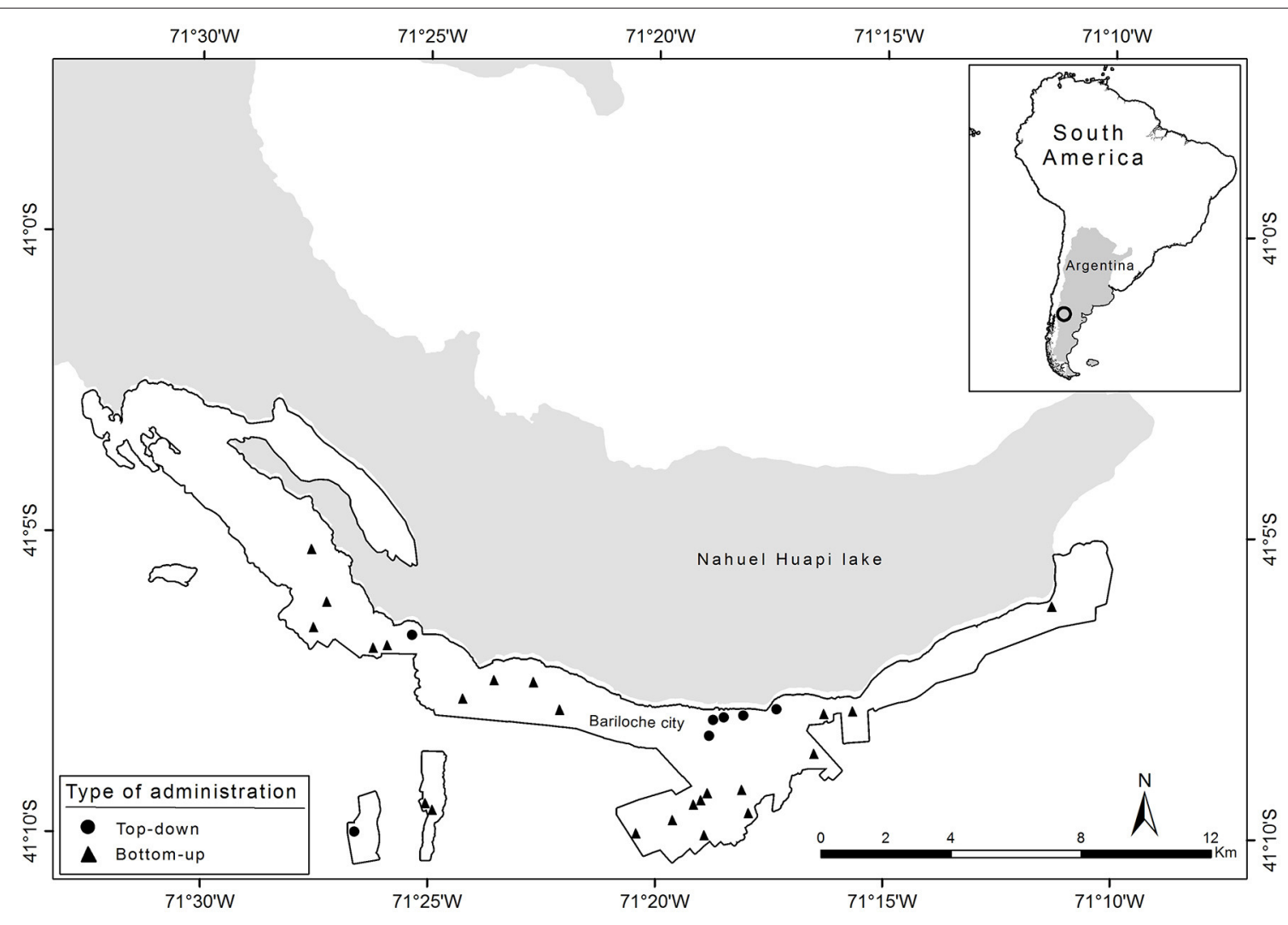

FIGURE 1 | Location of the study sites within Bariloche city, showing urban parks with bottom-up administration (circle) and top-down administration (triangle).

the country accidentally or intentionally were considered exotic species (Zuloaga et al., 2008). The biogeographic kingdoms of origin of the species (Holarctic, Paleotropical, Neotropical, Cape, Australian, or Antarctic) were determined by consulting bibliographical sources.

\section{Ethnoecological Field Methods}

Firstly, the consent of participants was obtained according to the Society of Ethnobiology Code of Ethics guidelines (ISE, 2006). The work was based on participant observation in the parks and personal interviews with key informants, preferably those either completely or partly in charge of managing these spaces. The key informants were specialists who had knowledge and experience of the practice in question (Albuquerque et al., 2010).

Special emphasis was placed on getting to know the people who actually looked after the parks, recording whether they were council employees, employees hired by the neighborhood committees or residents from the surrounding areas. Each of these individuals was consulted as to their responsibility regarding selection of the plants used, the criteria and type of management, age of the park, and type of administration. All this information was validated through participant and nonparticipant observation (compilation of records, photographs, articles, etc.) so as to become well informed as to the use of these spaces (Höft et al., 1999; Albuquerque et al., 2014).

\section{Age and type of Administration}

With regard to age of the parks, 6 categories were used: from 1-10 years old (1), 10-20 (2), 20-30 (3), 30-40 (4), $40-50$ (5), and over 50 years (6). For analysis of the type of administration, based on the interviews carried out and journalistic and council information, the administration types were classified as council (top-down) and neighborhood (bottom-up). The first corresponds to spaces maintained exclusively by squads of personnel from the Council Parks and Gardens department, while the parks with neighborhood management are administered and maintained by members of associations or neighborhood committees (either the members themselves or hired workers) and residents of the area.

\section{Environmental and Socio-Economic Gradient}

Categories were established for the environmental conditions where the parks are situated. These categories were based on previous knowledge and observation of each space, taking into account factors such as exposure to wind, precipitation and soil characteristics, which form part of the biophysical characterization of other, similar studies (Luck et al., 2009; Avolio et al., 2015). Values from 1 to 4 were established, based on the level of environmental stress, where (1) is high, with direct exposure to strong winds, precipitation at the low end of the 
range for the area (less than $800 \mathrm{~mm}$ annually) and poor soil; (2) is a medium to high level, characterized by considerable winds, medium to low precipitation $(800-1,000 \mathrm{~mm})$ and rather stony soil; (3) is medium to low, grouping sites with relatively low wind exposure, medium to high precipitation $(1,000-1,400 \mathrm{~mm})$ and soil which is less than favorable; finally, (4) represents low environmental stress, with low wind exposure, high levels of precipitation $(1,400-2,000 \mathrm{~mm})$ and fertile soils rich in organic material. The characteristics of wind exposure, precipitation and soil type were obtained from Dzendoletas et al. (2006) and Pereyra (2007).

The different socioeconomic levels of the city parks were also classified into categories, thus establishing possible socioeconomic gradients. To this end we considered the grouping carried out in 2009 and 2013, presented in reports from the Regional Studies Centre of the Universidad Fasta in Bariloche, in which socioeconomic categories were drawn up from information obtained through cadastral surveys in different neighborhoods of the city. This information was cross-checked with the income of the active working population and the value of the basic food basket, thus obtaining the following classification: low class, corresponding to the sector of the population whose income is no more than U\$S 980 per month; lower middle class, with an income of between U\$S 980 and U\$S 1,230; mid-middle class with U\$S 1,230 - U\$S 2,430; upper middle class with an income of U\$S 2,430 to U\$S 2,700; and finally, upper class, with salaries over U\$S 2,700. Following the criteria detailed above, each park was assigned one of the following categories: low class (1), lower middle class (2), mid-middle class (3), upper middle class (4) or upper class (5).

\section{Management Practices}

For analysis of management methods and cultural care, Casas et al. (1996) were followed, whose categories are based on consideration of the different human interventions in the landscape, divided into: in situ and ex situ. Management in situ refers to interactions carried out within the space occupied by the plant species and can be grouped as follows: tolerance (the vegetation established prior to human intervention is maintained in the space), enhancement (seeks to increase the population density of plants, an example being irrigation) and protection (refers to actions such as elimination of competing or predatory species, application of fertilizers, pruning, protection against frost, the use of stakes, etc.). In contrast, ex situ methods include human-plant interactions that take place outside the areas normally occupied by a plant species; these are habitats created and controlled by humans. Two classes are distinguished: the sowing of seeds or planting of cuttings (artificial propagation of reproductive or vegetative structures) and transplanting (the movement of complete individuals from natural sites or other humanized spaces, such as plant nurseries). This information was obtained during interviews with those in charge of maintenance and/or participant observation. A questionnaire was used to identify the different actions taken in relation to the species and the selection processes of the flora, and questions were asked about the design and maintenance work carried out in each park. This information was verified through direct observation of the cultural care currently in force and the richness of species established in each park, and was then entered in a database. The presence or absence of different practices was classified for each park as 1 or 0 , respectively.

\section{Data Analysis}

Quali-quantitative analysis of the ethnoecological data was carried out (Albuquerque et al., 2014). Due to the categorical nature of the data, the analyses were principally non-parametric and multinomial logistics, using the SPSS 23 package for Windows. Species richness was calculated per park and for all the parks studied; the number of native and exotic species was also determined, as well as the richness of botanical families per park and in total (Test Binomial and $X^{2}, p<0.05$; Conover, 1971). The mean richness of species per park was compared for exotics and natives (Mann-Whitney, $p<0.05$ ). The degree of invasion (DI) per park was compared under different management types (Mann-Whitney, $p<0.05)$, considering (DI) as the following:

$$
D I=\frac{\text { exotic richness }}{(\text { exotic }+ \text { native }) \text { richness }}
$$

In addition, a Poisson regression analysis was performed in order to evaluate relationships between exotic and native species for each type of administration (top-down and bottom-up). The relation between total species richness, the number of native and exotic species, and the area and age of the parks was evaluated (Spearman Correlation, $p<0.05$; Höft et al., 1999). The use consensus or cultural importance (CI) index, frequently used for analysis of ornamental species (Rovere et al., 2013), was calculated for the species and/or families (Ladio and Lozada, 2008; Molares and Ladio, 2009):

$$
C I=\frac{\text { no. of parks containing the species or family }}{\text { total no. of parks }} 100
$$

The Spearman correlation test $(p<0.05)$ was used to evaluate the association between total richness, including native and exotic species, and the categories describing the different environmental and socioeconomic conditions. Parks with bottom-up administration were compared with top-down (council) in terms of total species richness, richness of native and exotic species, and that of botanical families (X2, $p<0.05$; Conover, 1971). In addition, similarity in species compositionnative, exotic and total (native plus exotic) was analyzed using the Jaccard index (IJ)

$$
I J=\frac{c}{a+b+c} 100
$$

where $c$ is the number of species common to both types of management, $a$ is the number of species present in only one of the management categories and $\mathrm{b}$ is the number of species present in only the other type of management (Höft et al., 1999).

In addition, a multinomial logistic regression analysis was carried out with the SPSS $23.0^{\circledR}$ program in order to obtain a model which describes how the probability of different management types varied with the type of administration, 


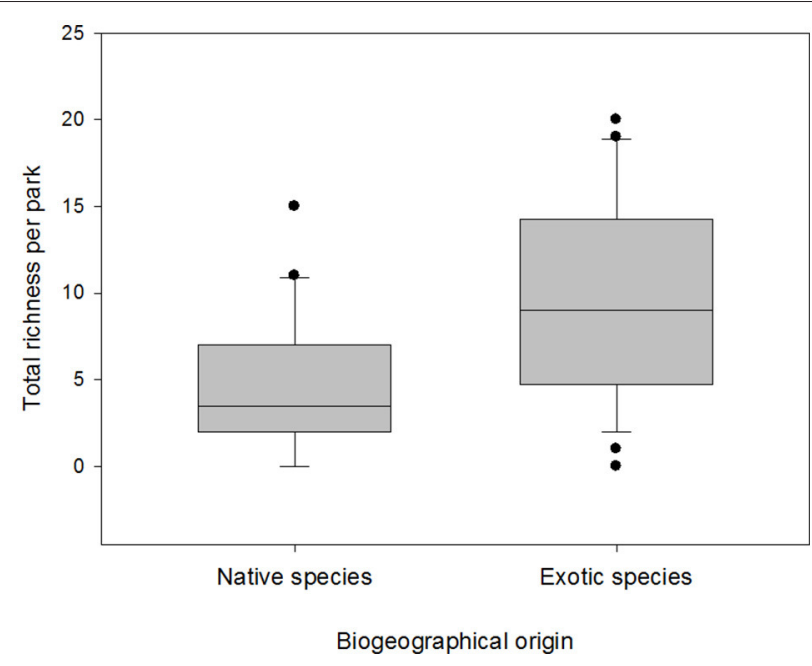

FIGURE 2 | Comparison of the biogeographical origin of plants found in urban parks of Bariloche. Boxes represent the interquartile range which contains $50 \%$ of the data. The black line within the boxes indicates the average, and the bars represent standard deviation (DS). Outliers are identified by black circle.

bottom-up or top-down (dependent categorical variable; Agresti, 1996; Chan, 2005). Thus, the algebraic model was $\ln \mathrm{p} / 1-\mathrm{p}=$ $\beta 0+\beta 1$ tolerance $+\beta 2$ enhancement $+\beta 3$ protection $+\beta 4$ sowing $+\beta 5$ transplanting, where $p / 1-p$ is the odds ratio; i.e., the probability that an event will happen in relation to the probability it will not. In this kind of regression, the tendencies are established according to the categories for comparison (in this case, the category bottom-up). The model allows us to see the impact of each of the factors in terms of controlling the other factors, and so the probability of each event occurring can be established. The model we found was significant $(p<0.05)$, with a high goodness of fit measure (Pearson and Deviance indices, $p$ $>0.05$ ). The calculations of the odds ratios (i.e., the probability of an event happening) were done by means of $\mathrm{e}^{\text {beta }}=\operatorname{Exp}$ (beta) (Agresti, 1996; Chan, 2005).

\section{RESULTS}

\section{Vegetation Composition}

As expected, considering global patterns in relation to useful plants, a total richness of 130 species was registered (Supplementary Table 1), of which $72 \%$ were exotic and $28 \%$ native species (Binomial test, $p<0.05$ ). These plants belong to 36 botanical families. We also found that mean exotic richness is significantly higher than for native species (Mann-Whitney test, $\mathrm{U}: 233, p<0.05$, Figure 2). However, no significant differences were found in degree of invasion (DI) between the different types of management (Mann-Whitney test, $\mathrm{U}: 69, p=0.57$ ). No relationship was found between richness of native and exotic plants for bottom-up $\left(r^{2}=0.01 ; p=0.708\right)$ or top-down $\left(r^{2}\right.$ $=0.36 ; p=0.157$ ) administration (Figure 3). The majority of plants present were identified to species level, except for 3 unidentified specimens, some other specimens which belonged

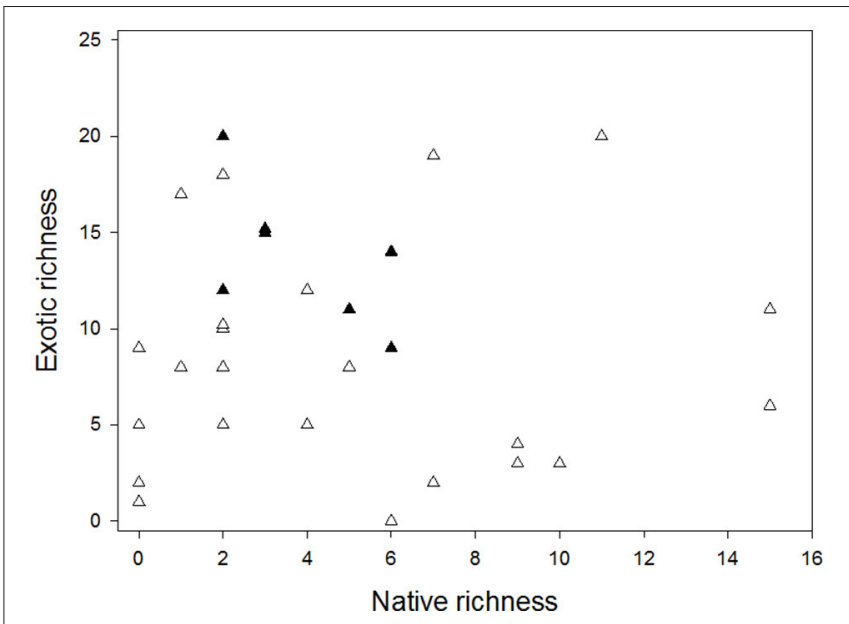

FIGURE 3 | Relationships between native and exotic plant richness in parks with top-down administration (black triangle) and bottom-up administration (white triangle).

to the Picea, Prunus, and Pyrus genera, some belonging to the Cupressaceae family and those belonging to the genus Rosa (except Rosa rubiginosa). The most frequently represented botanical families in the parks were Rosaceae (93\%) and Pinaceae (70\%) (Figure 4). The species with the highest CI were the native Maytenus boaria (57), the exotic Cytisus scoparius (53), Sorbus aucuparia (47), Betula pendula (43), Rosa sp. (43), the native Schinus patagonicus (43) and the exotic Prunus cerasifera (40) (Supplementary Table 1).

With regard to the biogeographical kingdom of origin of the species, $68 \%$ come from the Holarctic, 29\% from the Antarctic, $9 \%$ from the Paleotropical, and 5\% from the Neotropical kingdom (Supplementary Table 1). No species were identified in this case from the Cape or Australian kingdoms.

\section{Richness in Relation to Age and Size}

The parks studied range in size from 804 to $21,592 \mathrm{~m}^{2}, 4676$ $( \pm 4601) \mathrm{m}^{2}$ being the average size. A positive relationship was observed between the area of the park, total species richness and exotic species richness $(p<0.05 ; r=0.455 ; r=0.534$ respectively). Furthermore, total richness and exotic species richness were found to be positively correlated with the age of the park ( $p<0.05 ; r=0.644 ; r=0.675$ respectively). No significant correlation was found between the number of native species and the area or age of the park $(p=0.0820 ; r=-0.043$ and $p=0.924$; $r=0.018$ respectively).

\section{Richness across the Environmental and Socioeconomic Gradients}

The total species richness of parks was found to increase with the more favorable categories in both environmental $(r=0.418, p<$ $0.05)$ and socioeconomic $(r=0.636, p<0.05)$ terms. In addition, richness of both native and exotic species increased with the socioeconomic gradient category $r=0.453, p<0.05, r=0.496$, $p<0.05$ respectively). When considering the environmental 


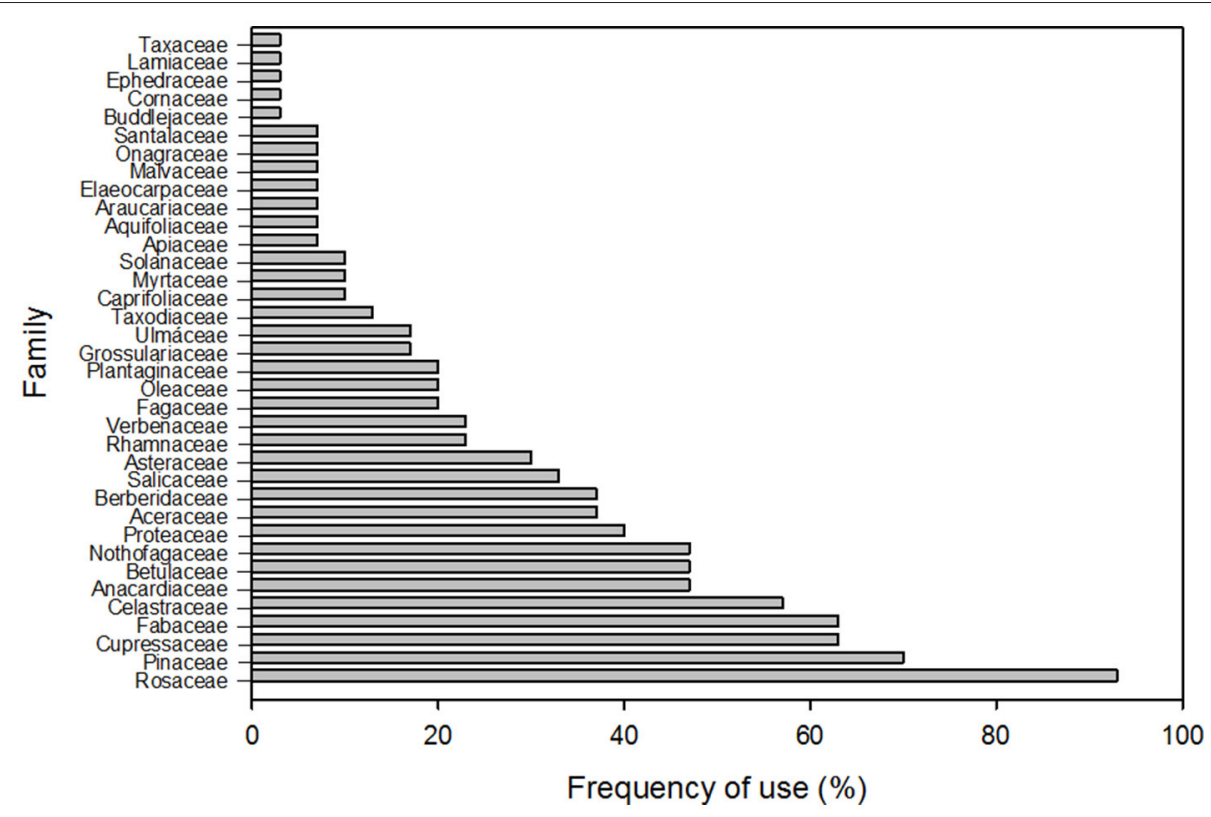

FIGURE 4 | Botanical families present in the parks of Bariloche, in order according to the $\mathrm{Cl}$ index.

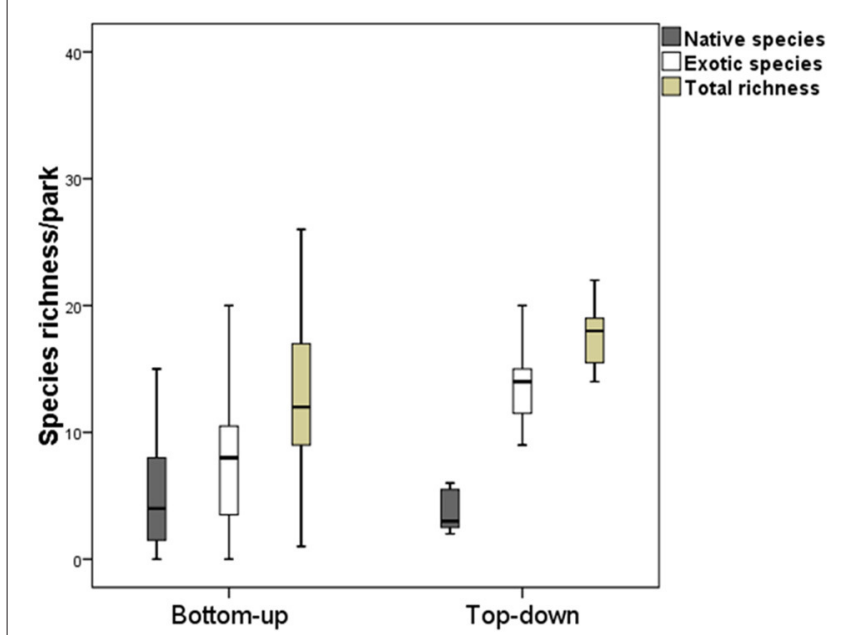

FIGURE 5 | Comparison of parks with council and neighborhood administration in terms of richness of native species, exotic species and total richness. The boxes represent the interquartile range which contains $50 \%$ of the data. The black line within the boxes indicates the average and the bars represent standard deviation (DS).

gradient, no relation was found between this and the number of native species $(r=0.252, p=0.18)$, or exotic species $(r=0.217$, $p=0.250)$.

\section{Bottom-Up vs. Top-Down Administration and Management Practices}

The management systems of the parks in Bariloche fall into 5 categories (both ex situ and in situ), the most frequent being

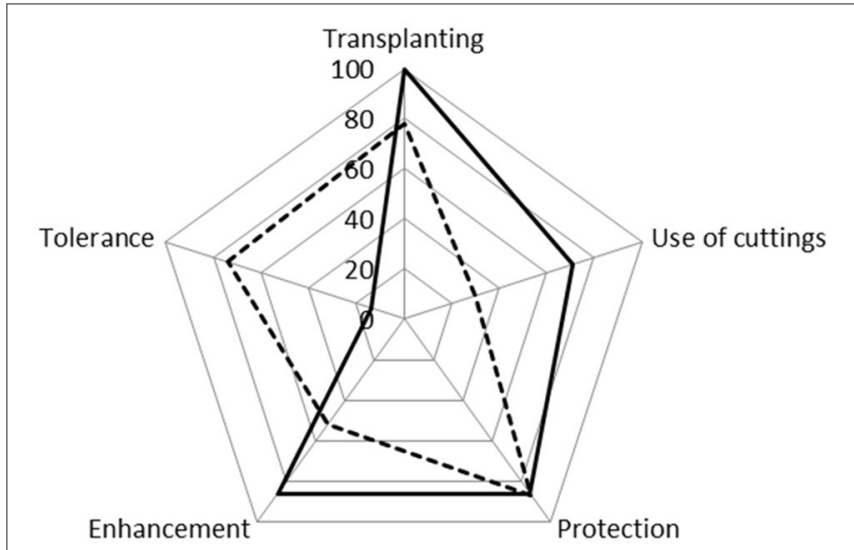

FIGURE 6 | Spider Chart showing the different forms of management (transplanting, planting of cuttings, protection, enhancement, and tolerance) registered in parks with neighborhood (bottom-up) and council administration (top-down). The solid lines correspond to top-down and the dashed lines to bottom-up administration.

protection $(87 \%)$, transplanting $(87 \%)$, tolerance $(60 \%)$, and enhancement $(60 \%)$. Cases of seed sowing in parks were not registered in this work. In the case of protection, the activities recorded were staking (33\% of the total number of parks) and pruning (77\% of all parks).

Most parks $(23,77 \%)$ are neighborhood-run (bottom-up), and are spaces whose maintenance is carried out by members of the corresponding neighborhood committees, associations or individual residents. Seven parks (23\%) are top-down managed, in the charge of squads from the Parks and Gardens department 
of Bariloche Local Council. The council-run parks hold 79 species in total, of which most are exotic (78\%). In the neighborhood parks, on the other hand, 99 species were found, of which $65 \%$ were exotic and 35\% native. Comparing the council-run (topdown) and neighborhood-run (bottom-up) parks, it was found that the former had significantly higher total richness (MannWhitney test, U: 39, $p<0.05$, Figure 5) and exotic species richness (Mann-Whitney test, U: $31, p<0.05$, Figure 5). No significant differences were found in the number of native species (Mann-Whitney test, U: 79, $p=0.962$ ), or in the area covered by the green spaces (Mann-Whitney test, $U: 56, p=0.245$ ) when the two types of management were compared. Total species similarity for the two types was $36 \%$ (IJ), for native species $46 \%$ (IJ), and for exotic species $32 \%$ (IJ).

As expected, the parks with bottom-up administration apply different management practices than the top-down administration. In the council administrated (top-down) parks, the most frequent practices are transplanting, enhancement and the planting of cuttings (Figure 6). The practices of protection, enhancement and transplanting, however, are more frequent in the neighborhood parks (bottom-up). The practice of protection is markedly similar in both park types $\left(X^{2}=0.007, p=\right.$ 0.933 , Figure 6). In the council parks the only means of protection registered is pruning, whereas in the neighborhood parks pruning was registered (74\%), but also the use of stakes $(43 \%)$.

Similarly, no significant differences were found between council and neighborhood parks for the practices of transplanting $\left(X^{2}=1.405, p=0.236\right)$ or enhancement, which includes irrigation and removal of competing species $\left(X^{2}\right.$ $=2.516, p=0.113$ ). In the neighborhood parks both irrigation and removal of competing species were registered, while in the council parks only irrigation was carried out. This occurs because the latter have areas covered by lawn, and so the appearance of other woody species is unlikely. Park irrigation is generally carried out by the residents/those in charge, by hand, with water being provided either from the park itself, outside sources (e.g., a house), or spray irrigation systems. Irrigation is used in $86 \%$ of council and $39 \%$ of neighborhood parks. As to the removal of competitive species, in this work the extraction of two exotic invasive species was registered-retama (Cytisus scoparius) and rosa mosqueta (Rosa rubiginosa) - in 5 neighborhood parks ( 3 of which had no irrigation). The practice of tolerance is significantly higher in bottom-up managed parks than in top-down ones (Binominal Test, $p<0.05$ ), while the planting of cuttings is more frequent in council parks, where pruning remains are taken advantage of, thus reducing the need to purchase plants (Binomial Test, $p<0.05$ ).

The practice of protection is similar in both types of park, although in the case of council administration this percentage represents pruning carried out to prevent branches breaking due to the weight of snow in winter. No staking, however, was registered in these parks, since they are older than the other ones in the city, and the plants are therefore adult specimens. In contrast, the neighborhood parks use the protection techniques of pruning and staking; the presence of stakes indicates that there are much younger plant specimens here. In relation to transplanting, no significant differences were found between the two types of park, although there was a tendency for this to be more common in council parks, given the high proportion of Rosas sp introduced through cuttings - these are in fact the only species to be introduced in this way.

The multinomial logistic regression model (Table 1) confirms the tendency mentioned above, considering all the factors together. The results show that although there are variations in forms of management depending on who is in charge of maintaining the parks, only tolerance differs significantly in the presence of the other forms of management (Table 1), being 13 times greater in neighborhood parks than in council ones $(\beta=$ 2.583).

\section{DISCUSSION}

\section{The Total Species Richness of Parks in Bariloche Reflects a Europeanizing Cosmovision}

In agreement with our first hypothesis, the species richness of parks in Bariloche is mainly composed of exotic species $(78 \%)$, an aspect which appears to be shared with other parks worldwide (Nagendra and Gopal, 2011; Linhares de Souza et al., 2012; Kowarik et al., 2013). The species found in Bariloche parks are common in local urban flora (Damascos et al., 1999) and in parks and public spaces throughout Argentina (Alvarez et al., 2009). In line with this, in terms of ornamental plant availability in local and regional plant nurseries, exotic species predominate over native ones. This could be a consequence of lack of knowledge of native plants or the techniques required for their cultivation, and also the preferences mentioned previously. In addition, exotic flora often present more rapid growth than many native species, and reproduce very well through vegetative propagation, and at a low cost Rosa, Cotoñaster, Photinia, Ligustrum, etc.). These plants are very attractive, both to tourists and residents, due to their diversity and contrasting leaf colors, and the size of their fruit and flowers.

Nevertheless, the exotic species used for ornamental purposes do present disadvantages in terms of cultural care, since they often require fertilizing, protection from frost, and more frequent watering. Their major impact, however, is doubtless their naturalization and invasion of ecosystems (Rovere et al., 2015). Native species, in contrast, have developed in the area and generally require less cultural care. They have co-evolved with pollinators and dispersers, and are very important for biodiversity. Native species form part of the local biocultural heritage, and so their diffusion not only helps to preserve natural ecosystems, minimizing the spread of exotic species, but also promotes appreciation of and respect for the local biocultural system.

The total richness of woody species registered in Bariloche parks (130 species), is similar in number to the ornamental woody species (137) used for hedging in eight Patagonian cities, including Bariloche (Rovere et al., 2013). These two 
TABLE 1 | Multinomial logistic regression model, considering type of administration as dependent variable. The presence or absence of management practices (tolerance, enhancement, protection, planting of cuttings and transplanting) was considered the independent variable.

\begin{tabular}{|c|c|c|c|c|c|c|c|c|}
\hline & Chi-squared & & df & Sig. & & & & \\
\hline \multicolumn{9}{|l|}{ (A) } \\
\hline Intersection & 0 & & 0 & & & & & \\
\hline Tolerance & 3.74 & & 1 & $0.053^{\star}$ & & & & \\
\hline Enhancement & 3.079 & & 1 & 0.079 & & & & \\
\hline Protection & 2.859 & & 1 & 0.091 & & & & \\
\hline Transplanting & & & $\beta$ & S.E. & Wald & df & Sig. & Exp(B) \\
\hline \multicolumn{9}{|l|}{ (B) } \\
\hline Type of adm. & Intersection & & 2.18 & 1.53 & 2.02 & 1 & 0.155 & \\
\hline \multirow{7}{*}{ Top-down } & & 1 & $0 b$ & & & 0 & & \\
\hline & Protection & 0 & 20.04 & $8,874.69$ & 0 & 1 & 0.998 & 504407748 \\
\hline & & 1 & $0 \mathrm{~b}$ & & & 0 & & \\
\hline & Use of cuttings & 0 & -0.39 & 1.61 & 0.06 & 1 & 0.808 & 0.68 \\
\hline & & 1 & ob & & & 0 & & \\
\hline & Transplanting & 0 & 17.07 & 0 & & 1 & & 0 \\
\hline & & 1 & $\mathrm{Ob}$ & & & 0 & & \\
\hline
\end{tabular}

(A) Likelihood ration test (B) Parameter estimations. Calculation of odds ratios (i.e., the probability that an event will occur) is shown with analysis of ebeta = Exp(beta). $\beta$, beta; S.E., standard error, Wald is the value of the Chi-squared test; $d f$, degrees of freedom; Sig., level of significance; and Exp( $\beta$ ), Odds ratios calculated (probability of occurrence of an event). *Significant values.

situations reflect similarity in the value placed on exotic plants as environmental assets of cultural importance, and reveal processes of construction of an anthropized landscape that have prioritized the showy species of Eurasia. Most species found in Bariloche parks correspond to the Holarctic biogeographical kingdom (68\%), following this tendency. This result coincides with the findings of Rozzi et al. (2003) in their analysis of native and exotic trees in the parks of Magallanes, in the south of Chile, where between 70 and $100 \%$ of the species are of European or North American origin.

It is important to note that the parks in Bariloche, of both administration types, are mainly used by local children and young people, while the top down parks are more frequently visited by tourists, given that they are mainly located in the downtown area. Nonetheless, we found no evidence to suggest that the preferences of tourists are considered by those who take care of the parks; decisions are made according to the particularities and preferences of local management.

Our results demonstrate in these landscapes the projection of conceptions and values of the hegemonic cultures which dominate the market, with species mainly from the northern hemisphere. In agreement with Rovere et al. (2013) in the case of hedges, the preferences of the first Swiss, German, and
Austrian immigrants have been strongly expressed in the city's parks, reproducing the "Argentine Switzerland" idea of landscape domestication.

The values found here for total richness indirectly show a set of actions over time, from the foundation of the city 115 years ago, which has molded the urban vegetation and favored certain plants over others. Based on a Eurocentric conception that what is most beautiful and valuable comes from that region, native biological and cultural diversity has been underestimated and undervalued (Rozzi et al., 2003; Roger et al., 2014). Where the city of San Carlos de Bariloche lies today, there lived indigenous Mapuche communities which were decimated during the Desert Campaign organized by the Argentine Government at the end of the nineteenth century (Moyano, 2017), and so all the biocultural richness of this region was also decimated and discriminated against.

Nevertheless, this bias in the domestication of park vegetation toward the construction of landscapes that are very distant from the native forests of the region, seems to have been undergoing a process of change in recent times. This is due to multiple factors rooted in changes occurring in the cosmovision of urban society, now moving toward its own ideas of conservationism. Although no indirect relation was found 
between the age of the parks and native plant richness, we did demonstrate a luxury effect in relation to native plants, such that parks situated in neighborhoods with higher socioeconomic levels are associated with higher native plant richness. The neighborhood-administrated parks, generally newer, have 13 times greater probability of finding practices of tolerance, evidencing greater interest in native plants.

It is to be expected that the presence of almost 30\% species of Antarctic origin in urban parks of Bariloche will increase in the future, especially with the spread of conservationist ideas on native flora, due to the mass media and environmental education programs in schools of the region. The temperate forest area of Argentina and Chile is home to many attractive, ornamental native species, which in fact are used in other parks and gardens around the world (Puntieri and Grosfeld, 2009). Historical records reflect patterns of colonialism in Patagonian urban flora, which has already been pointed out by Rapoport (1988) and reveals how profound processes of cultural domination markedly mold the landscapes, even those used for recreation.

The parks in San Carlos de Bariloche therefore constitute a model to be followed, in terms of species selection and management, at both regional and national levels. Even though exotic species still predominate, the parks are slowly being enriched with ornamental species from the temperate forest, and local residents are becoming involved in the care of these parks.

\section{Incipient Domestication of Native Plants?}

Although more research is required, our work enables us to assert that the different management practices and the use of some native ornamental species, as well as exotic species, reflect processes of incipient domestication processes in urban plots. For example, the native tree species Maytenus boaria, of great cultural importance in Bariloche parks and subjected to different practices of tolerance, protection and enhancement, is a case worthy of future study. This species is also the most frequently used for hedging, according to a study carried out in 8 Andean Patagonian cities (Rovere et al., 2013). It is a perennial tree with numerous uses (Rapoport et al., 2001), which tolerates constant pruning of its foliage in the maintenance of hedges and parks, and thermal protection due to urbanization. It has a high capacity for post-disturbance regeneration (Damascos et al., 1999) and its seeds are dispersed by urban birds (Amico and Aizen, 2005), attributes which confer a great adaptive capacity, therefore ideal for domestication.

This case shows how domestication is a collective process, with fluctuations in progress over time. Further research along these lines could be carried out to determine the genetic variability of native species growing in urban environments in comparison with those found in the surrounding wild areas.

It should be pointed out that the parks of Patagonia are important spaces for the conservation of our patrimony, both natural and cultural (Rozzi et al., 2003); they can contribute to the conservation of endemic and/or endangered species, where domestication takes on added value in terms of conservation of biodiversity.

\section{The Largest, Oldest Parks Hold More Anthropized Exotic Vegetation}

The average area of Bariloche parks is highly variable $\left(4,676 \pm 4,601 \mathrm{~m}^{2}\right)$, but in comparison with a study carried out on 22 parks in the city of Aracaju (Brazil), the area occupied by each park is significantly less (Linhares de Souza et al., 2012), revealing the need to increase the number or size of parks in the city.

In accordance with our second hypothesis, and as a consequence of the reasons mentioned above, the largest and oldest parks are those which have highest species richness, particulary considering exotic species, a pattern which has been found in other parks around the world. For example, in the parks of Aracaju (Brazil), 58\% of the plants are exotic species (Linhares de Souza et al., 2012). Changes in plant species have also been documented across urban gradients (Aronson et al., 2015; Threlfall et al., 2016). On analyzing the pattern of urbanization and the species richness of native and non-native woody species in the metropolitan region of New York, an urban-rural gradient was registered such that native species decrease and non-native species increase with urban coverage, and the flora is dominated by non-native species (Aronson et al., 2015), a pattern similar to that registered in the city of Berlin (Kowarik et al., 2013), and in other European cities.

In this work, however, native species richness did not vary with size or with the age of the park. Park age was not related to greater richness of native species since the older parks were designed in sectors with no vegetation, under the cosmovision of the time of their creation, and so mainly exotic species were used. Park size was not related to native species richness, but was possibly related to their abundance, given the higher density of species observed in larger parks. Since our analysis did not consider species abundance, our results are limited. Nevertheless, we can say indirectly that native plants continue to be represented in the parks due to the effects of particular sites which compensate for processes of anthropization with exotic plants, but there is probably a lower number of individuals in each of these areas.

On the other hand, the age of most Bariloche's urban parks is more than 10 years ( $93 \%$ of the parks), which allows us to say that the selection of exotic over native species has been prevalent in the history of Bariloche parks. Although the value of native flora is currently being given more importance, the effects of this will be seen in the medium or long term, together with an increase in new parks following a more conservationist cosmovision. In this study, in the older parks we have not seen the replacement of exotic trees with native trees; they have not been replaced because the trees are still healthy, and Bariloche society respects them as part of their tree cover. All we have seen is a woody species being eliminated if this species has been causing problems.

In general terms we can say that human activity, through management practices such as cultivation, protection, and enhancement, tends to increase the diversity of species in the zones where they are carried out (Berkes and Davidson-Hunt, 2006). In India the oldest parks have been recorded as having few large trees, but a higher diversity of species than newer or recently established parks, since the large trees are gradually replaced 
by trees of other, smaller species that are easier to maintain (Nagendra and Gopal, 2011). In our case, since Bariloche is a city with a short history (115 years since its foundation), these replacements have not been necessary, given that the longevity of the exotic species exceeds the age of most of the parks.

\section{Not All Parks Are the Same: Environmental and Socio-Economic Gradients}

In support of our second hypothesis, the total species richness of Bariloche's parks increases with better environmental and socioeconomic conditions. This coincides with the "luxury effect" mentioned by Hope et al. (2003). The neighborhoods with a better socioeconomic position, in general situated in the more ecologically favorable areas of the city, usually count on trained gardeners who are hired exclusively to maintain these green spaces.

Similarly, a study on urban trees in southern California found that socioeconomic situation was a more important driver than the environmental aspect, registering in general higher richness of trees in richer neighborhoods (Avolio et al., 2016). In addition, this shows that the species richness of urban trees is influenced by the preferences and perceptions of both managers and residents (Avolio et al., 2016). In our case this has a substantial effect, given that in the less environmentally and socioeconomically favorable sites, those involved in administering the parks have commented on limitations in terms of irrigation, pruning and adequate maintenance of the parks. The interviews suggest that if conditions were more favorable for maintenance of the species, the parks would be better managed and cared for than they are at present. We can therefore ensure that landscape domestication in urban parks has drivers which have been strongly established by the inequality of conditions found throughout the city.

Although we did not study in more detail whether educational level is an important factor in the tendency to change to parks with more native plants, we do not think that there is a linear relationship with the level of education. Our studies in rural areas with illiterate inhabitants always show that inhabitants value and care deeply for the environment.

\section{Top-Down vs. Bottom-Up Park Administration}

Council-run parks present higher total species and exotic species richness than neighborhood-run, but the two types of park are similar in terms of native species richness and degree of invasion. Furthermore, no relationship was found between richness of native and exotic species for each type of administration. Perhaps if species abundance (density or cover) had been considered, the effects of management would have been more evident. There is no doubt that the action of the council (as assessor or species donor) in the forestation of these green spaces is the most relevant factor in determining the composition of exotic species. The council parks, most of which are older and situated in sectors that were originally devoid of vegetation, are found ornamented mainly with foreign species. This arose mainly as a consequence of action carried out in the 1940s by the Isla Victoria National Plant Nursery (Vivero Nacional de la Isla Victoria), which formed part of the National Parks administration in its last years of existence, during which time it donated a percentage of its production to parks, public areas, schools and gardens (Vallmitjana, personal communication).

In contrast, the neighborhood parks, generally newer, had no support of this kind, and are scenarios where the practice of tolerance of some native plants are most frequent, together with the enrichment of new exotic species. One of the most interesting aspects is that native species richness does not vary between the two types of administration, probably due to the fact that both types have low richness, with high standard deviation; for example, if you compare them with forest remnants on vacant urban lots (Damascos et al., 1999). Most of the council-run parks had no woody specimens at the time of their creation, since the zone where the city now lies was converted from an agricultural colony, and the land had been totally cleared of vegetation. Therefore, the low tolerance is because there were no species to tolerate, rather it was reforested. The neighborhoodrun parks, on the other hand, already had much more plant coverage at the time of their creation, which was maintained, according to informants in the interviews. This was mainly due to conservationist criteria and/or in some cases, because of a lack of economic resources to extract the plants.

In support of our third hypothesis, bottom-up park management practices are different to top-down ones, although only tolerance differs notably. It has been suggested that the increase in use of exotic species for ornamentation of hedges and gardens brings with it the need for more management practices (Rovere et al., 2015). Since the exotic plants are not adapted to the climate, they require more cultural care, generating high costs and considerable maintenance time (Ramírez-Hernández et al., 2012). In contrast, the conservation of native species calls for fewer and less frequent management practices, principally enhancement and protection, since these species are adapted to the environmental conditions (Puntieri and Grosfeld, 2009). This would explain why enhancement practices are the most frequent in neighborhood parks, conserving in situ species that form part of the Andean Patagonian forests.

\section{CONCLUSION}

Landscape domestication processes in cities respond to sociobiocultural concerns. They generate a unique molding of local biodiversity, with possible ecological and genetic effects on the species selected. In particular, the comparison of different management practices documented in the bottom-up and topdown administrations reveal certain effects caused by man (whether through action or omission) in different processes of landscape domestication, the product of their varying possibilities and circumstances. The incipient domestication of some species reflects different cosmovisions and drivers, specific to particular pluricultural contexts, which should be studied further. We conclude that urban parks are unique cultural niches which, similar to agroforest systems, are scenarios that manifest the historical processes at work in their creation, and eventual cultural domination, but also processes of biocultural change. 
These unique urban niches are not static, but vary with the demands and experience of a Latin American city that gradually recognizes the value of its native plants, and the value of local biocultural diversity. Niches like those in Bariloche constitute a model that helps in understanding how multiple factors mold the landscape, due mainly to changes in cosmovision. In Bariloche it seems there is a tendency to value local, native elements more highly than before. Through management, the relation between native and exotic richness in each park can be modified. In the design of new parks or maintenance of existing ones, the strategy of gradually replacing exotic species for native ones should predominate, so as to maintain, enrich and recreate native environments in the urban matrix, in line with local socio-cultural interests. We trust that this work will help to guide management decisions toward conservation of the Andino Norpatagonica Biosphere Reserve, articulating top-down and bottom-up administration.

\section{AUTHOR CONTRIBUTIONS}

$\mathrm{AR}$ and $\mathrm{AL}$ conceptualized the study and planned the data design and data analysis. $\mathrm{RB}, \mathrm{AR}$, and $\mathrm{AL}$ collected the data and wrote

\section{REFERENCES}

Agresti, A. (1996). An Introduction to Categorical Data Analysis. New York, NY: John Wiley.

Albuquerque, U. P., Cunha, L. V. F., Lucena, R. F. P., and Alves, R. R. N. A. (2014). Methods and Techniques in Ethnobiology and Ethnoecology. New York, NY: Springer.

Albuquerque, U. P., Paiva de Lucena, R. F., and Cruz da Cunha, L. V. F. (2010). Métodos e Técnicas na Pesquisa Etnobiológica y Etnoecológica. Recife: Nupeea.

Alvarez, M., Arach, A., Arias, P., Contreras, M. R., Dalmau, I. B., et al. (2009). Árboles de San Martín de los Andes. Guía de reconocimiento. San Martín de los Andes: Asociación Civil Pro-Patagonia.

Amico, G., and Aizen, M. A. (2005). Dispersión de semillas por aves en un bosque templado de Sudamérica austral: ¿quién dispersa a quién? Ecol. Austral 15, 89-100.

Argañaraz, J. P., and Lorenz, G. (2010). Contribución de las áreas verdes urbanas a la regulación del balance de agua en Santiago del Estero, Argentina. Bosque 31, 231-242. doi: 10.4067/S0717-92002010000300007

Aronson, M. F. J., Handel, S. N., LaPuma, I. P., and Clemants, S. E. (2015). Urbanization promotes non-native woody species and diverse plant assemblages in the New York metropolitan region. Urban Ecosyst. 18, 31-45. doi: 10.1007/s11252-014-0382-z

Avolio, M. L., Pataki, D. E., Gillespie, T. W., Jenerette, G. D., McCarthy, H. R., Pincetl, S., et al. (2016). Tree diversity in southern California's urban forest: the interacting roles of social and environmental variables. Front. Ecol. Evol. 3:73. doi: 10.3389/fevo.2015.00073

Avolio, M. L., Pataki, D. E., Pincetl, S., Gillespie, T. W., Jenerette, G. D., and McCarthy, H. R. (2015). Understanding preferences for tree attributes: the relative effects of socio-economic and local environmental factors. Urban Ecosyst. 18, 73-86. doi: 10.1007/s11252-014-0388-6

Berkes, F., and Davidson-Hunt, I. J. (2006). Biodiversity, traditional management systems, and cultural landscapes: examples from the boreal forest of Canada. Int. Soc. Sci. J. 58, 35-47. doi: 10.1111/j.1468-2451.2006.00 605.x

Blancas, J., Casas, A., Rangel-Landa, S., Moreno-Calles, A., Torres, I., Perez-Negron, E., et al. (2010). Plant management in the TehuacanCuicatlan Valley, Mexico. Econ. Bot. 64, 287-302. doi: 10.1007/s12231-010-9 $133-0$ the manuscript. All the authors edited and revised drafts of the manuscript, approved the final version and agree to be held accountable for the work.

\section{ACKNOWLEDGMENTS}

This research was carried out with partial funding from the National Council of Scientific and Technical Research of Argentina (CONICET,) PIP: 0466 and PIP: 0196 assigned to Ana Ladio and Adriana Rovere respectively, and funding from Universidad Nacional del Comahue. We dedicate this work to the memory of our dearly loved Dr. Eddy Rapoport, who passed away in May, 2017, and who has left us an immense legacy of work in pursuit of biocutural conservation.

\section{SUPPLEMENTARY MATERIAL}

The Supplementary Material for this article can be found online at: https://www.frontiersin.org/articles/10.3389/fevo. 2017.00166/full\#supplementary-material

Casas, A., Blancas, J., Otero-Arnaiz, A., Cruse-Sanders, J., Avenda-o, A., Parra, F., et al. (2016). "Evolutionary ethnobotanical studies of incipient domestication of plants in Mesoamerica," in Ethnobotany of Mexico, eds R. Lira, A. Casas, and J. Blancas (New York, NY: Springer), 257-285.

Casas, A., Camou, A., Otero-Arnaiz, A., Rangel-Landa, S., Cruse-Sanders, J., Solís, L., et al. (2014). Manejo tradicional de biodiversidad y ecosistemas en Mesoamérica: el Valle de Tehuacán. Investig. ambient. cienc. Política Pública 6, 23-44.

Casas, A., Vfizquez, M. C., Viveros, J. L., and Caballero, J. (1996). Plant management among the nahua and the mixtec in the Balsas River Basin, Mexico: an ethnobotanical approach to the study of plant domestication. Hum. Ecol. 24, 455-478. doi: 10.1007/BF02168862

Chan, Y. H. (2005). Biostatistics 305. Multinomial logistic regression. Singapore Med. J. 46, 259-269.

Chebez, J. C. (2005). Guía de las Reservas Naturales de la Argentina: Patagonia Norte. Buenos Aires: Ed. Albatros.

Clement, C. R. (1999). 1492 and the loss of Amazonian crop genetic resources. I. The relation between domestication and human population decline. Econ. Bot. $53,188-202$.

Conover, W. J. (1971). Practical Nonparametric Statistics. New York, NY: John Wiley and Sons.

Correa, M. N. (1971). Flora Patagónica. Parte 7. Compositae. Buenos Aires: Colección Científica del INTA.

Correa, M. N. (1984). Flora Patagónica. Parte 4a. Dicotiledóneas Dialipétaleas (Salicaceae a Cruciferae). Buenos Aires: Colección Científica del INTA.

Correa, M. N. (1988). Flora Patagónica. Parte 4b. Dicotiledóneas Dialipétalas (Droseraceae a Leguminosae). Buenos Aires: Colección Científica INTA.

Damascos, M. A., Ghermandi, L., and Ladio, A. H. (1999). About the persistence of the native species of a Patagonian Austrocedrus chilensis forest. J. Ecol. Environ. Sci. 25, 21-35.

Dimitri, M. J. (1977). Peque-a flora ilustrada de los parques nacionales Andino Patagónicos. Anales de Parques Nacionales 13, 1-122.

Dimitri, M. J. (1978). Enciclopedia Argentina de Agricultura y Jardinería. Buenos Aires: Ed. Acme.

Duque-Brasil, R., Soldati, G. T., Espírito-Santo, M. M., Rezende, M. Q., DángeloNeto, S., and Coelho, F. M. G. (2011). Composição, uso e conservação de espécies arbóreas em quintais de agricultores familiares na região da mata seca norte- mineira, Brasil. Sitientibus Sér. Ci. Biol. 11, 287-297. doi: 10.13102/scb76 
Dzendoletas, M. A., Cavallaro, S., Crivelli, E., and Pereyra, F. (2006). Mapa de vegetación del ejido municipal de San Carlos de Bariloche y alrededores. Río Negro. Patagonia Argentina. Ecología 20, 65-88.

Eyssartier, C., Ladio, A. H., and Lozada, M. (2011). Traditional horticultural knowledge change in a rural population of the Patagonian steppe. J. Arid. Environ. 75, 78-86. doi: 10.1016/j.jaridenv.2010.09.006

Finol, J. E. (2005). Globalización, espacio y ritualización: De la plaza pública al mall. Espac Abierto, 14, 573-588.

González-Insuasti, M. S., and Caballero, J. (2007). Managing plant resources: how intensive can it be? Hum. Ecol. 35, 303-314. doi: 10.1007/s10745-006-9063-8

Grimm, N. B., Grove, J. M., Pickett, S. T. A., and Redman, C. L. (2000). Integrated Approaches to long-term studies of urban ecological systems. Bioscience 50, 571-584. doi: 10.1641/0006-3568(2000)050[0571:IATLTO]2.0.CO;2

Hobbs, R. J., Arico, S., Aronson, J., Baron, J. S., Bridgewater, P., and Cramer, V. A., et al. (2006). Novel ecosystems: theoretical and management aspects of the new ecological world order. Glob. Ecol. Biogeogr. 15, 1-7. doi: 10.1111/j.1466-822X.2006.00212.x

Höft, M., Barik, S. K., and Lykke, A. M. (1999). Quantitative Ethnobotany Applications of Multivariate and Statistical Analyses in Ethnobotany. Division of Ecological Sciences. Paris: UNESCO.

Hope, D., Gries, C., Zhu, W., Fagan, W. F., Redman, C. L., Grimm, N. B., et al. (2003). Socioeconomics drive urban plant diversity. Proc. Natl. Acad. Sci. U.S.A. 100, 8788-8792. doi: 10.1073/pnas.1537557100

INDEC (2010). Censo Nacional de Población, Hogares y Viviendas. Available online at: https://www.indec.gov.ar/nivel4_default.asp?id_tema_1=2\&id_tema_2= 41\&id_tema_3=135

Informe Ambiental Annual (2008). Gobierno de la Ciudad de Buenos Aires. Buenos Aires: Informe Ambiental Annual.

ISE (2006). International Society of Ethnobiology Code of Ethics. Chiang Rai.

Juri, M. D., and Chani, J. M. (2005). Variación en la composición de comunidades de aves a lo largo de un gradiente urbano (Tucumán, Argentina). Acta Zool. Lilloana 49, 49-57.

Kareiva, P., Watts, S., McDonald, R., and Boucher, T. (2007). Domesticated nature: shaping landscapes and ecosystems for human welfare. Science 316, 1866-1869. doi: $10.1126 /$ science. 1140170

Kendal, D., Williams, K. J. H., and Williams, N. S. G. (2012). Plant traits link people's plant preferences to the composition of their gardens. Landsc. Urban. Plan. 105, 34-42. doi: 10.1016/j.landurbplan.2011.11.023

Kowarik, I., von der Lippe, M., and Cierjacks, A. (2013). Prevalence of alien versus native species of woody plants in Berlin differs between habitats and at different scales. Preslia $85,113-132$.

Ladio, A. H., and Damascos, M. A. (2000). La invasión de plantas exóticas y la conservación de plantas nativas en baldíos suburbanos. Medio Ambiente 13, 27-34.

Ladio, A. H., and Lozada, M. (2008). "Medicinal plant knowledge in rural communities of Northwestern Patagonia, Argentina. A resilient practice beyond acculturation" in Current topics in Ethnobotany, eds U. P. Albuquerque and M. A. Ramos (Kerala), 40-53.

Laland, K. N., and O'Brien, M. J. (2011). Cultural niche construction: an introduction. Biol. Theory 6, 191-202. doi: 10.1007/s13752-012-0026-6

Linhares de Souza, A., Ferreira, R., De Mello, A., da Rocha Plácido, D., Zoaid Alves Dos Santos, C., et al. (2012). Diagnóstico quantitativo e qualitativo da arborização das praças de aracaju, SE. Rev. Árvore 35, 1253-1263. doi: 10.1590/S0100-67622011000700012

Luck, G. W., Smallbone, L. T., and O'Brien, R. (2009). Socio-economics and vegetation change in urban ecosystems: patterns in space and time. Ecosystems 12, 604-620. doi: 10.1007/s10021-009-9244-6

McKinney, M. L. (2006). Urbanization as a major cause of biotic homogenization. Biol. Cons. 127, 247-260. doi: 10.1016/j.biocon.2005.09.005

Molares, S., and Ladio, A. H. (2009). Ethnobotanical review of the Mapuche medicinal flora: use patterns on a regional scale. J. Ethnopharmacol. 122, 251-260. doi: 10.1016/j.jep.2009.01.003

Moreno-Calles, A., Casas, A., Blancas, J., Torres, I., Masera, O., Caballero, J., et al. (2010). Agroforestry systems and biodiversity conservation in arid zones: the case of the Tehuacan-Cuicatlan Valley, Central Mexico. Agrofor. Syst. 80, 315-331. doi: 10.1007/s10457-010-9349-0

Moreno-Calles, A., Casas, A., García-Frapolli, E., and Torres-García, I. (2012). Traditional agroforestry systems of multi-crop "milpa" and "chichipera" cactus forest in the arid Tehuacán Valley, Mexico: their management and role in people's subsistence. Agrofor. Syst. 84, 207-226. doi: 10.1007/s10457-011-9460-x

Moyano, A. (2017). A Ruego de mi Superior Cacique, Antonio Modesto Inakayal. Colección Trürüm. Viedma: Fondo Editorial Rionegrino.

Nagendra, H., and Gopal, D. (2011). Tree diversity, distribution, history and change in urban parks: studies in Bangalore, India. Urban Ecosyst. 14, 211-223. doi: 10.1007/s11252-010-0148-1

Ospina-Ante, A. (2003). Agroforestería. Aportes Conceptuales, Metodológicos y Prácticos Para el Estudio Agroforestal. Cali: Asociación del Colectivo de Agroecología del Suroccidente Colombiano.

Parra, F., Blancas, J. J., and Casas, A. (2012). Landscape management and domestication of Stenocereus pruinosus (Cactaceae) in the Tehuacán Valley: human guided selection and gene flow. J. Ethnobiol. Ethnomed. 8, 32-49. doi: 10.1186/1746-4269-8-32

Pataki, D. E. (2015). Grand challenges in urban ecology. Front. Ecol. Evol. 3:57. doi: $10.3389 /$ fevo.2015.00057

Pereyra, F. X. (2007). Geomorfología urbana de San Carlos de Bariloche y su influencia en los peligros naturales, Río Negro. Rev. Asoc. Geol. Argent. 62, 309-320.

Pincetl, S. (2016). Cities as novel biomes: recognizing urban ecosystem services as anthropogenic. Front. Ecol. Evol. 3:140. doi: 10.3389/fevo.2015.00140

Puntieri, J. G., and Grosfeld, J. E. (2009). Arbolado urbano en la patagonia andina: buscando el equilibrio. Desde La Patagonia Difundiendo Saberes, 6, 2-9.

Ramírez-Hernández, S. G., Pérez-Vázquez, A., Cruz García-Albarado, J., GómezGonzález, A., and de la Cruz Vargas-Mendoza, M. (2012). Criterios para la selección de especies herbáceas ornamentales para su uso paisajístico. Rev. Chapingo Ser. Hortic. 18, 71-79.

Rapoport, E. H. (1988). Lo bueno y lo malo tras el Descubrimiento de América. El punto de vista ecológico y biogeográfico. Arbor Consejo Superior Investigaciones Científicas Madrid 131, 103-125.

Rapoport, E. H., Ladio, A. H., and Sanz, E. H. (2001). Plantas Nativas Comestibles de la Patagonia Andina Argentino-Chilena. Bariloche: Imaginaria.

Rodríguez-Laredo, D. M. (2008). El Valor Ecológico, Ornamental y de uso Tradicional de las Especies Nativas de la Ciudad de La Paz. Dissertation Thesis. Universidad de San Andrés, La Paz.

Roger, E., Generoso, M., Blanco, R., and Villaverde, A. (2014). Caracterización de la flora le-osa en Plaza Libertad, Santiago del Estero. Quebracho 22, 50-56.

Rovere, A. E., and Molares, S. (2012). "Una estrategia inter-jurisdiccional para el control de especies ornamentales invasoras," in Eco-sociedad 2012: Bosque (Esquel: Ruralidad Urbanismo), 256-263.

Rovere, A. E., Molares, S., and Ladio, A. H. (2013). Plantas utilizadas en cercos vivos de ciudades patagónicas: aportes de la etnobotánica para la conservación. Ecol. Austral 23, 165-173.

Rovere, A. E., Molares, S., and Ladio, A. H. (2015). "Cercos vivos en la flora de una ciudad de la patagonia semiárida argentina: especies preferidas e implicancias para la restauración ecológica," in Restauración Ecológica en la Diagonal Árida de la Argentina, eds E. Martínez Carretero and A. D. Dalmasso (Mendoza: IADIZA), 429-442.

Rozzi, R., Massardo, F., Silander, J., Dollenz, O., Connolly, B., Anderson, C., et al. (2003). Árboles nativos y exóticos en las plazas de Magallanes. An. Inst. Patagon. $31,27-42$.

Rudd, H., Vala, J., and Schaefer, V. (2002). Importance of backyard habitat in a comprehensive biodiversity conservation strategy: a connectivity analysis of urban green spaces. Restor. Ecol. 10, 368-375. doi: 10.1046/j.1526-100X.2002.02041.x

Saillard, M. (1962). “Infraestructure," in Urbanisme (Paris).

Smith, B. D. (2011). A cultural niche construction theory of initial domestication. Biol. Theory 6, 260-271. doi: 10.1007/s13752-012-0028-4

Smith, B., and Zeder, M. (2013). The onset of the Anthropocene. Anthropocene 4, 8-14. doi: 10.1016/j.ancene.2013.05.001

Tella, A. G., and Potocko, L. A. (2009). Los espacios verdes públicos: Una delicada articulación entre demanda y posibilidades efectivas. Merc. Empr. 55, 40-55.

Threlfall, C. G., Ossola, A., Hahs, A. K., Williams, N. S. G., Wilson, L., and Livesley, S. J. (2016). Variation in vegetation structure and composition across urban green space types. Front. Ecol. Evol. 4:66. doi: 10.3389/fevo.2016. 00066 
UNESCO (2010). Biosphere Reserves World Network 564 in 109 Countries. The MAB programme. Available online at: http://unesdoc.unesco.org/Ulis/cgi-bin/ ulis.pl? catno $=217380 \&$ set $=0057$ B32D7D_2_244\&gp $=0$ \&lin $=1 \& 11=1$

Van Herzele, A., and Wiedemann, T. (2003). A monitoring tool for the provision of accessible and attractive urban green spaces. Landsc. Urban Plan. 63, 109-126. doi: 10.1016/S0169-2046(02)00192-5

Zeder, M. A. (2015). Core questions in domestication research. Proc. Natl. Acad. Sci. U.S.A. 112, 3191-3198. doi: 10.1073/pnas.1501711112

Zuloaga, F. O., Morrone, O., and Belgrano, M. J. (2008). Catálogo de las Plantas Vasculares del Cono Sur: (Argentina, Sur de Brasil, Chile, Paraguay y Uruguay). St. Louis, MO: Missouri Botanical Garden Press.
Conflict of Interest Statement: The authors declare that the research was conducted in the absence of any commercial or financial relationships that could be construed as a potential conflict of interest.

Copyright (c) 2017 Betancurt, Rovere and Ladio. This is an open-access article distributed under the terms of the Creative Commons Attribution License (CC $B Y)$. The use, distribution or reproduction in other forums is permitted, provided the original author(s) or licensor are credited and that the original publication in this journal is cited, in accordance with accepted academic practice. No use, distribution or reproduction is permitted which does not comply with these terms. 